\title{
La tercera misión
}

\section{The third mission}

\section{Francisco José García-Peñalvo}

Departamento de Informática y Automática, Instituto de Ciencias de la Educación, Grupo GRIAL, Director Científico, Editor-In-Chief Education in the Knowledge Society Journal, Universidad de Salamanca, España. fgarcia@usal.es

\section{Resumen}

El editorial de este primer número del volumen 17, correspondiente al año 2016, se dedica a las relaciones universidad-empresa-sociedad en lo que se conoce como la Tercera Misión de la Universidad o como la misión de la transferencia de conocimiento.

\section{Palabras clave}

Tercera misión; Transmisión de conocimiento; Alianza de conocimiento universidad-empresa

\begin{abstract}
The editorial of this first issue of volume 17 , corresponding to 2016, is devoted to the university-business-society relationships that is usually known as Third Mission of the University or the knowledge transfer mission.
\end{abstract}

\section{Keywords}

Third mission; Knowledge transfer; Universitybusiness knowledge alliance

A finales del siglo XX, en el contexto de la construcción de una Sociedad del Conocimiento (Bell, 1973), surge, especialmente con foco en el Reino Unido, una corriente crítica del papel, misión y función de la Universidad. Como consecuencia de este proceso de reflexión se incorpora a sus dos funciones básicas de enseñanza superior e investigación una tercera misión clave para la sociedad: "producir conocimiento aplicable y fomentar la innovación, formar y reciclar profesionales cualificados a lo largo de la vida, valorizar la investigación y fomentar proyectos emprendedores o llevar a cabo proyectos de desarrollo territorial en colaboración con el resto de agentes del sistema económico" (ACUP, 2008).

Esta tercera misión incluye tareas muy diversas que son difíciles de clasificar, que involucran desde la formación continua de los profesionales, con un especial énfasis en la formación eLearning (García-Peñalvo \& Seoane-Pardo, 2015), hasta la creación de proyectos empresariales y la inserción de laboral de titulados y doctores. En general, el paradigma de la tercera misión se basa en dos pilares principales, por un lado la responsabilidad social institucional de la universidad; y, por otro, el compromiso de transformar el conocimiento en valor económico, incidiendo en la competitividad y facilitando la innovación, la creatividad y el desarrollo cultural, científico y tecnológico (Vilalta, 2013). Es decir, los ejes principales de esta tercera misión son el emprendimiento, la innovación y el compromiso social (Bueno Campos \& Casani, 2007), lo que es congruente con los conceptos que se 
desarrollan a finales de la década de los noventa sobre la universidad emprendedora (Clark, 1998) y la universidad como agente de la denominada triple hélice, universidad-empresa-administración (Etzkowitz \& Leydesdorff, 1997).

Las relaciones universidad-empresa son imprescindibles para el éxito de la tercera misión. Sin embargo los indicadores y las experiencias de quienes participan activamente en el desarrollo de estas relaciones muestran que existe una gran distancia entre estos dos actores. La Unión Europea, consciente de este problema, promueve varios programas para estrechar esta colaboración, siendo el Erasmus+ Key Action 2 - Knowledge Alliances el que desde 2013 implementa estas iniciativas en Europa.

Un indicador que refleja la distancia entre la universidad y la empresa en España, y que pone de manifiesto el mucho camino que queda por recorrer, es la poca presencia de doctores en las empresas españolas. La tasa de doctores empleados en el sector empresa en España, en 2009, es inferior al 16\%, mientras que para los países miembros de la OCDE la tasa está sobre el 30\%, cifra que es sumamente superior en el caso de Estados Unidos, 44\%, o Francia, 62\%, por poner algunos ejemplos. Teniendo en cuenta además que la producción de doctores en España está en cifras equiparables a otros países del entorno, ocupando la undécima posición mundial en el año de referencia (2009) (Benito Bonito, Gil Torrubias, \& Romera Ayllón, 2014).

El compromiso social de las universidades tiene que reflejarse también en su apuesta por la mejora de la empleabilidad de sus egresados y el poder transformador de la educación sobre las personas y la comunidad, pudiendo servir como medio de ascenso social a las primeras y de impulso al conjunto de la población (Portabella, 2016). En este sentido, el Observatorio de Empleabilidad y Empleo Universitarios (https://oeeu.org/) de la Cátedra UNESCO de Gestión y Política Universitaria de la Universidad Politécnica de Madrid ha publicado los resultados del I Barómetro de Empleabilidad y Empleo Universitarios en España (Michavila, Martínez, Martín-González, García-Peñalvo, \& CruzBenito, 2016), cuyo sistema de información ha sido realizado por el Grupo GRIAL (García-Peñalvo et al., 2012) de la Universidad de Salamanca (Michavila, Martín-González, Martínez, García-Peñalvo, \& Cruz-Benito, 2015).

Esta tercera misión de las universidades quedaba patente cuando se planteaba el mapa de la innovación educativa y se dedicaba un espacio para la extensión institucional (García-Peñalvo, 2015b). En este contexto ya se mencionaba la empleabilidad y de forma muy relacionada las prácticas de los estudiantes en las empresas.

El proyecto VALS (Virtual Alliances for a Learning Society) (García-Peñalvo, 2015a; García-Peñalvo, CruzBenito, Conde, \& Griffiths, 2014, 2015; García-Peñalvo, Cruz-Benito, Griffiths, \& Achilleos, 2016; García- 
Peñalvo, Cruz-Benito, Griffiths, et al., 2014), ubicado dentro del Programa de Knowledge Alliances de la Unión Europea, es un claro ejemplo de práctica de innovación que intenta reducir la distancia entre la universidad y la empresa. Promueve el establecimiento de alianzas de conocimiento entre entidades de educación superior y el mundo de los negocios a través empresas, fundaciones y proyectos, para llevar a cabo procesos de innovación abierta en la que se tienden puentes entre ambos mundos, el académico y el de los negocios, permitiendo una retroalimentación de lo mejor de ambos en pos de un objetivo común de desarrollo e innovación basado en filosofías abiertas (Open Source (Open Source Initative, 2012), Open Innovation (Chesbrough, 2003), Open Knowledge (García-Peñalvo, García de Figuerola, \& Merlo-Vega, 2010a, 2010b)). Esta colaboración, según plantea este proyecto, se instrumenta a través del desarrollo de prácticas en empresas y proyectos a nivel internacional que planteen problemas reales de negocio por parte de estudiantes, de informática y áreas de conocimiento afines, que estudian en entidades educativas europeas; en un proceso reglado a través del establecimiento de un sistema de recompensas y retribuciones (no económicas) del cual salen beneficiados todos los actores involucrados (enfoque win-win) (García-Peñalvo, Cruz-Benito, Griffiths, \& Achilleos, 2015).

De las diferentes lecciones aprendidas en el proyecto VALS se destaca que no es suficiente contar con una buena práctica y la infraestructura que permita desarrollarla para lograr su éxito y su completa adopción por los actores involucrados, las prácticas virtuales en este caso concreto. La realidad que separa la academia del mundo empresarial, la resistencia al cambio y a abandonar sus respectivas zonas de confort por parte de los principales actores, y las diferencias de organización y estructura de las diferentes universidades europeas (y no solo debidas a estar en diferentes países) han sido factores determinantes para conseguir una velocidad de adopción de los procedimientos propuestos muy por debajo de la esperada (García-Peñalvo, 2014), lo que de nuevo pone de manifiesto la distancia existente y el enorme camino que queda por recorrer para tener una cultura de la transferencia de conocimiento entre universidad-empresa-sociedad totalmente asentada y que lleve a una universidad más alineada con la sociedad del conocimiento (Berlanga, García-Peñalvo, \& Sloep, 2010; GarcíaPeñalvo, 2011) y las reglas de juego que se erigen sobre una infraestructura de información que crece exponencialmente en lugar de sobre una perspectiva más industrial y estática (Stevenson, 2011).

\section{Contenidos del número}

Este primer número del volumen 17 incluye siete artículos regulares. El primero de ellos lleva por título "Evaluación sostenible de experiencias de aprendizaje basadas en proyectos" y ha sido realizado por Traverso-Ribón et al. (2016). En este trabajo se describe una metodología de evaluación orientada al aprendizaje y un framework software de datos abiertos aplicable a la evaluación de proyectos de desarrollo colaborativo. Se han elaborado una rúbrica y una serie de indicadores que proporcionan 
evidencias sobre las habilidades y, posteriormente, se han aplicado a un curso basado en proyectos de pequeña escala. La experiencia ha proporcionado evidencias a favor del método de evaluación y el framework de datos abiertos para hacer la evaluación del trabajo en equipo más sostenible.

El siguiente artículo "Motivation and academic improvement using augmented reality for 3D architectural visualization" ha sido realizado por Fonseca Escudero et al. (2016). Este artículo discute los resultados de evaluar el grado de motivación, el perfil y el nivel de satisfacción de los estudiantes en flujos de trabajo que utilizan la visualización aumentada de modelos complejos en 3D. Los resultados muestran como los estudiantes partícipes han mejorado sus resultados académicos y su implicación con la materia, un punto clave en el actual marco educativo compuesto por estudiantes nativos digitales y un gran número de aplicaciones y dispositivos para la enseñanza y el aprendizaje.

En el tercer artículo, que lleva por título "Una experiencia de aprendizaje combinado en Estadística para estudiantes de Psicología usando la evaluación como herramienta de aprendizaje" y ha sido realizado por Valentín Centeno et al. (2016), se presenta una experiencia que combina enfoques que priorizan el uso de las TIC (Tecnologías de la Información y la Comunicación, con otros donde la evaluación se convierte en un elemento de aprendizaje para la enseñanza de Estadística Aplicada a la Psicología. El desarrollo de esta experiencia ha mostrado cómo la propuesta didáctica ha sido interpretada positivamente por los estudiantes. Los estudiantes reconocieron que tenían que aprender y comprender en profundidad los conceptos básicos de la asignatura, para que ellos puedan enseñar y evaluar a sus compañeros.

Inês Araújo (2016) es la autora del cuarto artículo "Gamification: metodologia para envolver e motivar alunos no processo de aprendizagem", en el que presenta una revisión de la literatura sobre el concepto de gamificación, describiendo algunos ejemplos relevantes que hacen que sea más fácil de entender cómo se puede implementar, proponer preguntas para reflexionar sobre la hora de aplicar esta nueva metodología a los contextos educativos.

El quinto de artículo lleva por título "Lectura Musical en el ámbito digital; aplicaciones para tablets" (Merchán Sánchez-Jara, 2016). En él se analizan las características y los procesos más genéricos dentro de la lectura musical, las formas y aplicaciones más comunes de estos modelos de lectura y se describen brevemente los sistemas de notación y los códigos más utilizados. Además, se analiza el desarrollo y uso de las nuevas aplicaciones para la lectura musical en dispositivos electrónicos.

En el artículo "Análisis y evaluación de las competencias del Grado en Información y Documentación en la Universidad de Zaragoza" (Agustín Lacruz \& Salvador Oliván, 2016) se estudian las competencias específicas descritas en las guías docentes publicadas del grado en Información y Documentación de la Universidad de Zaragoza. 
En el último de los artículos, los investigadores del proyecto europeo VALS (García-Peñalvo et al., 2013; García-Peñalvo, Cruz-Benito, Griffiths, et al., 2015; García-Peñalvo, Cruz-Benito, et al., 2016) discuten los resultados de la evaluación llevada a cabo en el proyecto con el propósito de reflexionar sobre las lecciones aprendidas en el proceso de prácticas virtuales propuesto (García-Peñalvo, Griffiths, CruzBenito, Veenendaal, Achilleos, Wilson \& Kapitsaki, 2016).

In the late twentieth century, in the context of building a Knowledge Society (Bell, 1973), a critical current arises about the role, mission and function of the University, especially focusing on UK. As a result of this reflection process, University incorporates a third mission to the its two basic functions of higher education and research. This third mission is key for the society: "producing applicable knowledge and fostering innovation, training and retraining qualified professionals throughout life, appraising research and promoting entrepreneurial projects or conduct territorial development projects in collaboration with other agents in the economic system" (ACUP, 2008).

This third mission is related to many different tasks that are not easy to classify. They involve from professionals' lifelong learning, with a special emphasis on eLearning methodology (García-Peñalvo \& Seoane-Pardo, 2015) to the creation of business projects and labour insertion of graduates and doctors. In general, the paradigm of the third mission is based on two main pillars. First, the corporate social responsibility of the university, and, on the other hand, a commitment to transforming knowledge into economic value, contributing to the competitiveness and facilitating innovation, creativity and cultural, scientific and technological development (Vilalta, 2013). That is, the main axes of this third mission are entrepreneurship, innovation and social commitment (Bueno Campos \& Casani, 2007). This is consistent with the concepts developed in the late nineties on the Entrepreneurial University (Clark, 1998) and the University as agent in the so known triple helix: university-business-administration (Etzkowitz \& Leydesdorff, 1997).

University-business relationships are essential to the success of the third mission. However, the indicators and the developed experiences show a big gap between these two actors. European Union is aware of this problem and promotes several programmes oriented to strength this collaboration. Erasmus+ Key Action 2 - Knowledge Alliances Programme is the reference action since 2013 to implement these initiatives in Europe.

An indicator that reflects the existing gap between University and Business in Spain, which means the wide road to walk in this sense, is the low presence of PhDs in the Spanish companies. PhD ratio in the Spanish business sector, in 2009, is lower than 16\%, while in OECD country members this ratio is over $30 \%$, a figure that is vastly superior in the case of the US, $44 \%$, or France, $62 \%$, to give some examples. Noting further that the production of doctors in Spain is comparable figures for other 
neighbouring countries, because Spain occupies the eleventh position worldwide in the reference year (2009) (Benito Bonito et al., 2014).

The social commitment in the universities has to be also reflected in their bet by the improving the employability of their graduates and by the education transformation power over the people and community, because of it may serve as a means of social promotion to the individuals and impulse to the whole population (Portabella, 2016). According to this, the Observatory of University Employability and Employment (https://oeeu.org/) of the University Management and Policy UNESCO chair at the Tech University of Madrid has published the results of the I Barometer about Spanish University Employability and Employment (Michavila et al., 2016), whose information system has been developed by GRIAL research group (García-Peñalvo et al., 2012) of the University of Salamanca (Michavila et al., 2015).

This third mission of the universities was presented in the educational innovation map area devoted to institutional extension (García-Peñalvo, 2015b). In this context, the employability and the students' internships were specially mentioned.

VALS (Virtual Alliances for a Learning Society) project (García-Peñalvo, 2015a; García-Peñalvo, CruzBenito, Conde, \& Griffiths, 2014, 2015; García-Peñalvo, Cruz-Benito, Griffiths, \& Achilleos, 2016; García-Peñalvo, Cruz-Benito, Griffiths, et al., 2014), within the European Union Knowledge Alliances Programme, is a good representative of innovation practice oriented to reduce the university-business gap. It promotes promotes the establishment of knowledge alliances among Higher Education Institutions and the Business world through corporations, foundations and projects, to carry out open innovation processes creating collaboration bridges between the Academia and Business, which allows obtaining feedback from the best of both in pursuit of a common goal of development and innovation based on open philosophies (Open Source (Open Source Initative, 2012), Open Innovation (Chesbrough, 2003), Open Knowledge (García-Peñalvo, García de Figuerola, \& Merlo-Vega, 2010a, 2010b)). The collaboration proposed by this project is implemented through the development of practices in companies and projects worldwide that pose real business problems by students that study computer sciences and other related areas in European educational institutions, in a process regulated by establishing a system of rewards and non-economic compensations which benefits all stakeholders (a win-win approach) (García-Peñalvo, Cruz-Benito, Griffiths, \& Achilleos, 2015).

From VALS experience and its lessons learned it is interesting to underline that is not enough having a good practice and the infrastructure that allows its development in order to be success and achieve a full adoption by the involved actor, the virtual placements in this specific case. The separating reality from business academy; the resistance to change and to leave their comfort zones by the main actors; and the differences about organization processes and structures in the European universities (even 
in the same country) have been the decisive factors in achieving a speed of adoption of the proposed procedures well below the expected (García-Peñalvo, 2014). This again shows the distance and the huge road that lies ahead for a culture of knowledge transfer between university-business-society fully seated, proper to a more aligned university with the Knowledge Society (Berlanga, García-Peñalvo, \& Sloep, 2010; García-Peñalvo, 2011) and with the rules that are built on an information infrastructure that grows exponentially rather than on an industrial and static perspectives (Stevenson, 2011).

\section{Contents of the issue}

This first volume 17 issue includes seven regular papers. The first one is entitled "Sustainable assessment of learning experiences based on projects" by Traverso-Ribón et al. (2016). This work describes a learning-oriented evaluation methodology and an open data framework that can be applied to collaborative project settings. An evaluation rubric and a series of indicators that provide evidences about the developed skills have been elaborated and applied in a small-scale project-based course. Projects were managed and developed with the help of an open source software forge that contains a ticketing tool for planning and tracking of tasks, a version control repository to save the software outcomes, and using a wiki to host text deliverables. The experience provides evidences in favour of using the assessment method and open data framework to make teamwork evaluation more sustainable.

Next paper "Motivation and academic improvement using augmented reality for 3D architectural visualization" by Fonseca Escudero et al. (2016) discusses the results from the evaluation of the motivation, user profile and level of satisfaction in the workflow using 3D augmented visualization of complex models in educational environments. The results show us how the students involved in the experiments improved their academic results and their implication in the subject, which allow us to conclude that the hybrid technologies improve both spatial skills and the student motivation, a key concept in the actual educational framework composed by digital-native students and a great range of different applications and interfaces useful for teaching and learning.

The third paper "A blended learning experience in Statistics for Psychology students using the evaluation as a learning tool" by Valentín Centeno et al. (2016) presents an experience that combines approaches that prioritize the use of ICT (Information and Communication Technologies) with other where evaluation becomes an element of learning in a course of Applied Psychology. This has involved the use of virtual platforms to support teaching that facilitate learning and activities where no face-toface are combined. The development of this experience has shown how the didactic proposal has been positively interpreted by students. Students recognized that they had to learn and deeply understand the basic concepts of the subject, so that they can teach and assess their peers.

Inês Araújo (2016) is the author of the fourth paper "Gamification: methodology to engage and 
motivate students in the learning process". It is devoted to present a literature review on the concept of gamification, describing some relevant examples that make it easier to understand how it can be implemented, proposing questions to ponder when applying this new methodology to educational contexts.

The fifth paper is entitled "Music Reading in digital environments: Apps for tablets" (Merchán SánchezJara, 2016). It analyses the most generic characteristics and processes amongst musical reading and describes the most common forms and applications of these reading models and the most widely used codes and notation systems. Although, it analyses the development and use of new technologies for reading music in electronic devices.

En el se analizan las características y los procesos más genéricos dentro de la lectura musical, las formas y aplicaciones más comunes de estos modelos de lectura y se describen brevemente los sistemas de notación y los códigos más utilizados. Además, se analiza el desarrollo y uso de las nuevas aplicaciones para la lectura musical en dispositivos electrónicos.

In the paper "Analysis and evaluation of the skills of the Degree in Information and Documentation at the University of Zaragoza" (Agustín Lacruz \& Salvador Oliván, 2016) the specific skill described in the teaching guides of the Degree in Information and Documentation of the University of Zaragoza are studied.

In the last paper, researchers of VALS European Project (García-Peñalvo et al., 2013; García-Peñalvo, Cruz-Benito, Griffiths, et al., 2015; García-Peñalvo, Cruz-Benito, et al., 2016) discuss the results of the evaluation work carried out in the project with the aim to reflect about the lessons learned from the proposed virtual placement process (García-Peñalvo, Griffiths, et al., 2016).

\section{Referencias}

ACUP. (2008). Libro Blanco de la Universidad de Cataluña. Barcelona: Associació Catalana d'Universitats Públiques.

Agustín Lacruz, M. C., \& Salvador Oliván, J. A. (2016). Análisis y evaluación de las competencias del Grado en Información y Documentación en la Universidad de Zaragoza. Education in the Knowledge Society, 17(1), 129-145. doi:http://dx.doi.org/10.14201/eks2016171129145

Araújo, I. (2016). Gamification: metodologia para envolver e motivar alunos no processo de aprendizagem. Education in the Knowledge Society, 77(1), 87-107. doi:http://dx.doi.org/10.14201/ eks201617187107 
Bell, D. (1973). The coming of post-industrial society: A venture in social forecasting. New York, USA: Basic Books.

Benito Bonito, M., Gil Torrubias, P., \& Romera Ayllón, R. (2014). El empleo de los doctores en España y su relación con la I+D+i y los estudios de doctorado. Las Palmas de Gran Canaria, España: Conferencia de Consejos Sociales de las Universidades Españolas.

Berlanga, A. J., García-Peñalvo, F. J., \& Sloep, P. B. (2010). Towards eLearning 2.0 University. Interactive Learning Environments, 18(3), 199-201. doi:http://dx.doi.org/10.1080/10494820.2010.500498

Bueno Campos, E., \& Casani, F. (2007). La tercera misión de la Universidad. Enfoques e indicadores básicos para su evaluación. Economía Industrial, 366, 43-59.

Chesbrough, H. W. (2003). Open innovation: The new imperative for creating and profiting from technology: Harvard Business Press.

Clark, B., Oxford. (1998). Creating entrepreneurial universities: Organizational pathways of transformation. Oxford: Pergamon.

Etzkowitz, H., \& Leydesdorff, L. (1997). Universities and the Global Knowledge Economy. A triple of a Triple Helix of University-Industry-Government Relations. London: Pinter.

Fonseca Escudero, D., Redondo Domínguez, E., \& Valls, F. (2016). Motivation and academic improvement using augmented reality for 3D architectural visualization. Education in the Knowledge Society, 17(1), 45-64. doi:http://dx.doi.org/10.14201/eks20161714564

García-Peñalvo, F. J. (2011). La Universidad de la próxima década: La Universidad Digital. In C. Suárez-Guerrero \& F. J. García-Peñalvo (Eds.), Universidad y Desarrollo Social de la Web (pp. 181-197). Washington DC, USA: Editandum.

García-Peñalvo, F. J. (2014). VALS Project - One year after. Paper presented at the Thematic Cluster Meeting "Knowledge Alliances" in Brussels at November 7th, 2014. http://hdl.handle.net/10366/125221

García-Peñalvo, F. J. (2015a). Entrepreneurial and problem solving skills in software engineers. Journal of Information Technology Research, 8(3), iv-vi. 
García-Peñalvo, F. J. (2015b). Mapa de tendencias en Innovación Educativa. Education in the Knowledge Society (EKS), 16(4), 6-23. doi:http://dx.doi.org/10.14201/eks2015164623

García-Peñalvo, F. J., Álvarez Navia, I., García-Bermejo, J. R., Conde-González, M., García- Holgado, A., Zangrando, V., Seoane-Pardo, A. M., Cruz-Benito, J., Lee, S., Elferink, R., Veenendaal, E., Zondergeld, S., Griffiths, D., Sharples, P., Sherlock, D., de Toni, A. F., Battistella, C., Tonizza, G., de Zan, G., Papadopoulos, G. A., Kapitsaki, G., Achilleos, A. P., Mettouris, C., Cheung, S., Guerrero, Z., He, E., Alier, M., Mayol, E., Casany, M. J., Wilson, S., Wilson, R., \& Johnson, M. (2013). VALS: Virtual Alliances for Learning Society. In F. J. García-Peñalvo, A. García-Holgado, \& J. Cruz-Benito (Eds.), Proceedings of the TEEM'73 Track on Knowledge Society Related Projects (pp. 19-26). Salamanca, Spain: Grupo GRIAL.

García-Peñalvo, F. J., Cruz-Benito, J., Conde, M. Á., \& Griffiths, D. (2014). Virtual placements for informatics students in open source business across Europe 2014 IEEE Frontiers in Education Conference Proceedings (October 22-25, 2014 Madrid, Spain) (pp. 2551-2555). USA: IEEE.

García-Peñalvo, F. J., Cruz-Benito, J., Conde, M. Á., \& Griffiths, D. (2015). Semester of Code: Piloting Virtual Placements for Informatics across Europe Proceedings of Global Engineering Education Conference, EDUCON 2015. Tallinn, Estonia, 18-20 March 2015 (pp. 567-576). USA: IEEE.

García-Peñalvo, F. J., Cruz-Benito, J., Griffiths, D., \& Achilleos, A. P. (2015). Tecnología al servicio de un proceso de gestión de prácticas virtuales en empresas: Propuesta y primeros resultados del Semester of Code. IEEE VAEP-RITA, 3(1), 52-59.

García-Peñalvo, F. J., Cruz-Benito, J., Griffiths, D., \& Achilleos, A. P. (2016). Virtual placements management process supported by technology: Proposal and firsts results of the Semester of Code. IEEE Revista Iberoamericana de Tecnologías del Aprendizaje (IEEE RITA), 17(1). doi:http://dx.doi. org/10.1109/RITA.2016.2518461

García-Peñalvo, F. J., Cruz-Benito, J., Griffiths, D., Sharples, P., Willson, S., Johnson, M., Papadopoulos, G. A., Achilleos, A. P., Alier, M., Galanis, N., Conde, M. Á., Pessot, E., Elferink, R., Veenendaal, E., \& Lee, S. (2014). Developing Win-Win Solutions for Virtual Placements in Informatics: The VALS Case. In F. J. García-Peñalvo (Ed.), Proceedings of the Second International Conference on Technological Ecosystems for Enhancing Multiculturality (TEEM'74) (pp. 733-738). New York, USA: ACM. doi:10.1145/2669711.2669982

García-Peñalvo, F. J., García de Figuerola, C., \& Merlo-Vega, J. A. (2010a). Open knowledge management 
in higher education. Online Information Review, 34(4), 517-519.

García-Peñalvo,F.J.,García deFiguerola,C., \&Merlo-Vega, J.A.(2010b). Open knowledge: Challenges and facts. Online Information Review, 34(4), 520-539. doi:http://dx.doi.org/10.1108/14684521011072963

García-Peñalvo, F. J., Griffiths, D., Cruz-Benito, J., Veenendaal, E., Achilleos, A. P., Wilson, S. \& Kapitsaki, G. (2016). Understanding the barriers to virtual student placements in the Semester of Code. Education in the Knowledge Society, 17(1), 147-173. doi:http://dx.doi.org/10.14201/eks2016171147173

García-Peñalvo, F. J., Rodríguez-Conde, M. J., Seoane-Pardo, A. M., Conde-González, M. Á., Zangrando, V., \& García-Holgado, A. (2012). GRIAL (GRupo de investigación en InterAcción y eLearning), USAL. IE Comunicaciones. Revista Iberoamericana de Informática Educativa(75), 85-94.

García-Peñalvo, F. J., \& Seoane-Pardo, A. M. (2015). Una revisión actualizada del concepto de eLearning. Décimo Aniversario. Education in the Knowledge Society, 16(1), 119-144. doi:http://dx.doi. org/10.14201/eks2015161119144

Merchán Sánchez-Jara, J. F. (2016). Lectura Musical en el ámbito digital: Aplicaciones para tablets. Education in the Knowledge Society, 17(1), 109-128. doi:http://dx.doi.org/10.14201/eks2016171109128

Michavila, F., Martín-González, M., Martínez, J. M., García-Peñalvo, F. J., \& Cruz-Benito, J. (2015). Analyzing the employability and employment factors of graduate students in Spain: The OEEU Information System. In G. R. Alves \& M. C. Felgueiras (Eds.), Proceedings of the Third International Conference on Technological Ecosystems for Enhancing Multiculturality (TEEM'75) (Porto, Portugal, October7-9,2015)(pp. 277-283). NewYork,USA:ACM. doi:http://dx.doi.org/10.1145/2808580.2808622

Michavila, F., Martínez, J. M., Martín-González, M., García-Peñalvo, F. J., \& Cruz-Benito, J. (2016). Barómetro de Empleabilidad y Empleo de los Universitarios en España, 2015 (Primer informe de resultados). Madrid: Observatorio de Empleabilidad y Empleo Universitarios.

Open Source Initative. (2012). The Open Source Definition. Retrieved from http://opensource.org/ docs/osd

Portabella, J. (2016). Presentación. Barómetro de Empleabilidad y Empleo de los Universitarios en España, 2015 (Primer informe de resultados) (pp. 8-9). Madrid: Observatorio de Empleabilidad y Empleo Universitarios. 
Stevenson, M. (2011). Un viaje optimista por el futuro (2a ed.). Barcelona: Galaxia Gutenberg.

Traverso-Ribón, I., Balderas-Alberico, A., Dodero, J. M., Ruiz-Rube, I., \& Palomo-Duarte, M. (2016). Evaluación sostenible de experiencias de aprendizaje basadas en proyectos. Education in the Knowledge Society, 17(1), 19-43. doi:http://dx.doi.org/10.14201/eks2016171943

Valentín Centeno, A., González-Tablas Sastre, M. M., López Pérez, M. E., \& Mateos García, P. M. (2016). Una experiencia de aprendizaje combinado en Estadística para estudiantes de Psicología usando la evaluación como herramienta de aprendizaje. Education in the Knowledge Society, 17(1), 65-85. doi:http://dx.doi.org/10.14201/eks20161716585

Vilalta, J. M. (2013). La tercera misión universitaria. Innovación y transferencia de conocimientos en las universidades españolas. Madrid: Studia XXI. Fundación Europea Sociedad y Educación. 